\title{
A Lot, But Not Yet Enough - A Call for More Action on Sustainability
}

Commonwealth Journal of Local Governance

\section{Grahame Collier}

Director of T Issues Consultancy

Australia

Email:grahame@tissues.com.au

\section{Rebecca Jones}

Director of Sustain Me Consulting

Australia

Email:Rebecca@sustainmeconsulting.com.au.

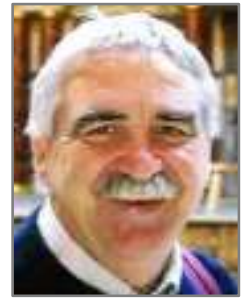

\begin{abstract}
The Urban Sustainability Support Alliance (USSA) was a large and multi-faceted NSW wide programme, which was delivered between late 2007 and late 2011, to support NSW Councils in integrating environmental sustainability into their policies, procedures, operations and programs. To support cultural change in 152 government instrumentalities, of different sizes, shapes and demographics, required innovation, connection and credibility. A diverse range of support and development mechanisms was required.
\end{abstract}

The USSA coined the tag line: Supporting Councils on their journey towards sustainability, and was evaluated in 2011. This paper charts the journey and reports on that evaluation. It describes the USSA program: provides judgments about the value of the programme against its intended outcomes; and identifies formative findings for the future so that the necessary support might continue.

The USSA was a highly successful program, with more than $85 \%$ of respondents from almost $80 \%$ of Councils in NSW indicating that the USSA had raised the profile of sustainability 'a lot'/'a reasonable amount/some'. Of these, 48\% indicated that the effect had been substantial. The evaluation report concluded that the USSA has provided 'a lot, but not yet enough' support to NSW Councils on the journey towards sustainability, and that there is still more to do.

\section{Introduction - about the urban sustainability alliance}

The Urban Sustainability Support Alliance (USSA) Programme supported NSW Councils in their journey towards sustainability. The programme was coordinated by the Local Government NSW (formerly the Local Government and Shires Associations - LGSA) and was funded by the NSW Environmental Trust.

In the context of this program, the term 'sustainability' refers to the capacity to meet the environmental needs of local communities, while encouraging current and future actions that aim for 
beneficial social, economic and environmental outcomes. At both the local and programme level, this required engagement of a wide range of stakeholders to build strong, effective partnerships to enable long term change.

The USSA was formed by a partnership of organisations that saw immense value in working together to help NSW Councils journey towards sustainability. The organisations representing a unique mixture of both State and Local Governments, a university institution, and a peak environmental body, banded together to form an alliance. The alliance model was particularly attractive to the funding body who had received separate applications for funding from each of the individual organisations. The applications shared a common objective around capacity building for sustainability in Local Government and this was the beginnings of the USSA, and its state-wide focus to improve the sustainability of NSW councils.

The USSA provided advice and information, conducted training and professional development workshops, developed tools and resources, promoted key learning and supported network development, cooperation and partnership between councils and stakeholders.

The USSA offered support to all NSW Councils and this presented a range of challenges; 152 Councils across NSW, meant 152 different approaches to sustainability and civic leadership. These approaches ranged from those had historically ignored the issues, often because of lack of resources or understanding, to others that saw sustainability as the driver of all of their policy, activities and operations. In order to be both relevant and useful, the support delivered needed to be tailored to the individual needs of Councils and their staff, varying in depth and complexity depending on where Councils were on their sustainability journey. Support services offered varied from intensive and active, to lower key and more passive.

\section{Intensive support}

Professional development: including in-house training for all Council staff, one-day workshops for regional groups of Councils, skills based train-the-trainer, half day training for Councillors.

Meetings and networks: meetings around a community of practice, on-line forum, specialised membership-only network for leaders, face-to-face meetings and phone advice meetings.

\section{More passive support}

Research and resources: Sustainability Health Check, 'How to' learning guides, case studies and an online resource database.

Communication: Email and phone help line, quarterly newsletters, a website and you- tube channel, guidance materials and online information, and networking through sustainable-net ${ }^{49}$.

\footnotetext{
${ }^{49}$ Sustainablenet is an on-line forum for those interested in sustainability. It currently has 622 Members from Councils across NSW Register online at www.sustainablenet.org.au
} 
For more information about the range of support provided visit the LGNSW website www.lgnsw.org.au

Support for driving sustainability forward in Councils is a relatively new concept with little data available on what makes an effective support program. Other jurisdictions have much to learn from the NSW approach and here in NSW there is much further to go to ensure that sustainability is central to all Council business. The evaluation of the USSA programme (LGSA 2011) is ground-breaking in terms of its role in assessing the types of support services that are needed to help NSW Councils on their journey.

\section{Sustainability in local government in NSW - a policy context}

In order to be effective, the USSA functioned within and reflected a significant public policy context. Council drivers for action on sustainability are many and varied (Pillora S, Blackburn N, Artist S, 2009). NSW Councils are on the sustainability journey for a range of reasons including senior management support especially from the General Manager, Mayor and Councillor Leadership, active and engaged community involvement and local media coverage of global and local sustainability issues.

One driver that impacts on all NSW Councils, large or small, is how sustainability is framed within current legislation. In summary, information is provided below about the relevant legal requirements that all NSW Councils are bound to and how the USSA used this to gain buy-in and support:

The NSW Local Government Act 1993 (Section 7a) states that local government's role is: 'to provide the legal framework for an effective, efficient, environmentally responsible open system of local government in NSW'. The Act (Section 7e) also requires:

Councils, Councillors and Council employees to have regard to the principles of Ecologically Sustainable Development in carrying out their responsibilities'.

This Act as amended in 1997 (Section 8) also sets out the requirement for a Council to "properly manage, develop, protect, restore, enhance and conserve the environment of the area for which it is responsible in a manner which is consistent with and promotes the principles of Ecologically Sustainable Development' and 'to have regard to the long term and cumulative effect of its decisions'.

In addition, an objective of the Environmental Planning and Assessment Act (1979) is: 'to encourage Ecologically Sustainable Development'. By inference, therefore, planning instruments which are developed under this Act should be founded on the principles of ESD.

A major development during the life of the USSA project was the Local Government Amendment (Planning and Reporting) Act 2009; and section 402 refers to the development of the ten-year Community Strategic Plan promoting all future activity within a sustainability framework that:

- identifies the main priorities and aspirations for the local government area 
- establishes strategic objectives together with related strategies addressing social, environmental, economic and civic leadership issues in an integrated manner

- ensures that the Community Strategic Plan is adequately informed through consultation relating to social, environmental, economic and civic leadership issues.

The establishment of long term community strategic planning provided a perfect opportunity for the USSA to engage with Councils on sustainability. The programme was able to help Councils begin to integrate environmental sustainability into their operations, policies and programs. It continues to provide a relevant framework for the future.

\section{Evaluating the USSA - the methodology}

This section describes the complex evaluation methodology for the program. It is developed within the context of programme logic (Funnell 1997 and Funnell 2000) and further developed in Rogers 2008.

The USSA was funded to meet eight objectives. For the purpose of the programme evaluation these were restated as six outcomes, constant for the life of the project. Outcomes were framed as a hierarchy as described by Funnel 1997 and Funnel 2000. The intended outcomes for the programme were:

1. The USSA assists Councils in developing, clarifying and promoting an urban sustainability vision and agenda for action.

2. The USSA cultivates networks and alliances of those working to innovate and make change.

3. The USSA identifies existing resources and tools and helps link these to Council's urban sustainability work.

4. The USSA identifies, facilitates, conducts and promotes relevant research.

5. The USSA promotes learning through professional development/training, advice and support.

6. The USSA builds the profile of sustainability work within local government and amongst opinion leaders.

Through the end-stage evaluation process a further outcome was added

7. The need for ongoing support for Local Government in NSW to continue to progress towards integrating sustainability.

The intent of the evaluation was both summative and formative (Funnel and Rogers 2011). Summative, in the sense that it captured and reported on the work that the USSA has undertaken, the role it has played and the impact of that work in Councils; formative, in that the evaluation was designed to inform a case for a continuation of a sustainability support service for Local Government. 
The USSA coined the tag line: Supporting Councils on their Journey towards Sustainability. Essentially the programme evaluation acted as a marker in that journey.

Because of the complex and long term nature of the program, and the relatively limited resources committed to end stage evaluation, the methodology was purpose built for the program. It comprised two elements, each related to collecting and analysing data against outcomes.

Element 1: Continuing evaluation processes were undertaken through the life of the program. All programme components were evaluated and the methodology varied depending on the nature of the activity that was being delivered. This range of data was substantial and was drawn together at the end of the programme to inform the Findings. Often this data was provided to the funding body as a part of regular project reporting and parts of it were reported on within the USSA website.

Element 2: End stage evaluation was undertaken in the final two months of the program. This was necessary in order to obtain additional data so that the Outcomes could be assessed, especially Outcomes 6 and 7. The end stage evaluation methodology used additional data collection tools, namely:

An on-line survey: A survey was developed and Councils were informed about the opportunity to complete the survey by way of a multifaceted and targeted information strategy. The survey was live for a period of four weeks and individual results were confidential.

Focus group/key informant interviews: One specific evaluative focus group was conducted, with participants joining the group via webinar and in person. Membership of the focus group was determined by a random sample selection process where participants were derived from a USSA Excel database of Council contacts across a spread of Councils, metro, regional and rural. In addition, eight key informant interviews were conducted, using the same discussion guide, which extended the data.

\section{Findings - what did the USSA achieve?}

This Section outlines the key findings against each of the outcomes for the project. The detailed findings are extensive and impossible to reproduce in detail in this paper. They have been provided to the USSA in an in-depth report (LGSA 2011).

In discussing these findings it is important to acknowledge that the Urban Sustainability Support Alliance [USSA] has had a culture of evaluation since its inception. Most individual support elements were evaluated in an ongoing way, so data was available from the commencement of the program, and is reflected in these findings.

End stage evaluation methods were also well supported, and much of the data reported upon below comes from the end stage methods. In particular, a significant amount of data was able to be gleaned 
from the survey because the response rate was high. The following provides a snapshot of survey respondents:

- Two hundred and six Council staff and elected officials responded.

- More than $71 \%$ of individual Councils responded [108 Councils], although the percentage response is higher than this, given that three Regional Organisations of Councils also responded and represented the views of their 32 member Councils.

- Responses were received from a range of Councils (Graph 1).

Graph 1. Survey responses: participating Councils

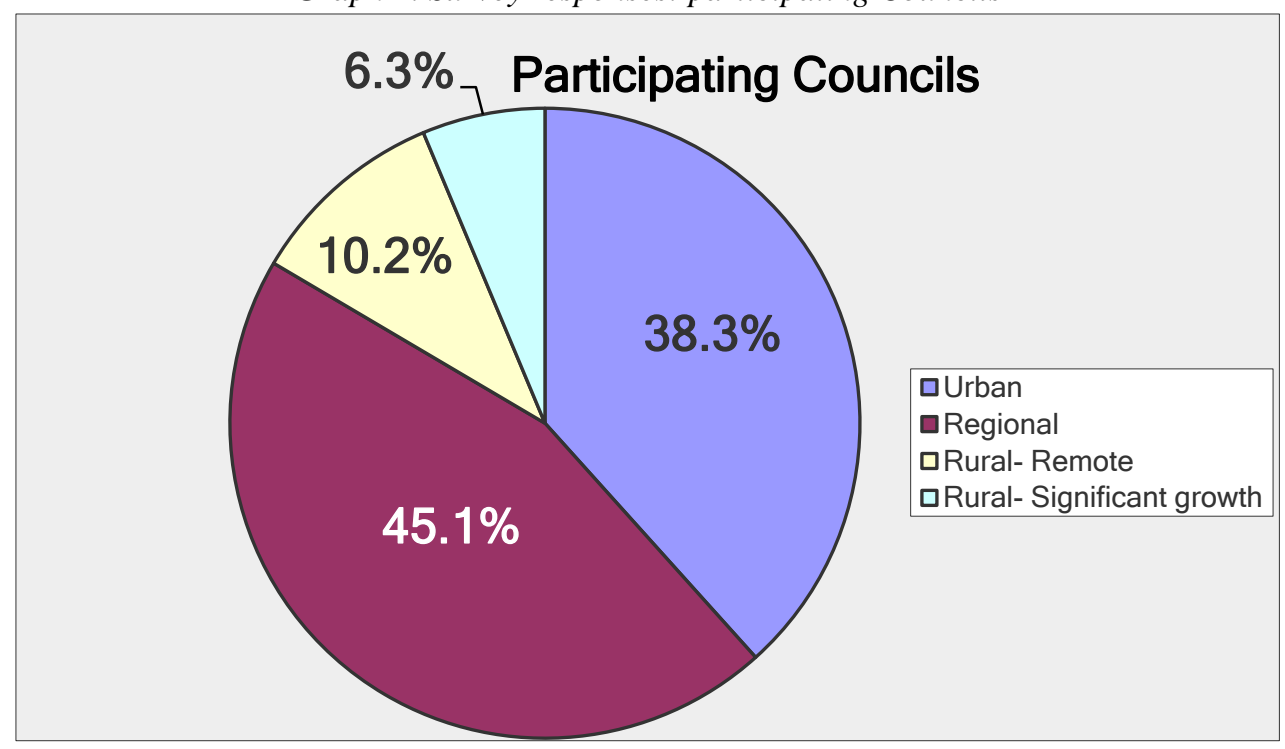

Only $1.9 \%$ of the responses came from elected officials. Staff across a range of Council functions provided data, with most drawn from the environment sections of Council, as follows:

$\begin{array}{lll}\circ & \text { Executive } & 8.3 \% \\ \circ & \text { Planning } & 15.0 \% \\ \circ & \text { Operations } & 0.5 \% \\ \circ & \text { Compliance } & 0.5 \% \\ \circ & \text { Engineering } & 6.3 \% \\ \circ & \text { Community Services } & 1.5 \% \\ \circ & \text { Environmental/ Sustainability } & 53.9 \% \\ \circ & \text { Administration } & 2.4 \% \\ \circ & \text { Other/misc } & 11.7 \%\end{array}$

Finding re Outcome 1. There is evidence that the USSA assists Councils in developing, clarifying and promoting an urban sustainability vision and an agenda for action. The USSA has had a significant level of influence on progressing sustainability in local government:

It was catalytic through its presence and the activity that it made happen. (Council respondent from key informant interview)

As indicated in Graph 2 below, more than $85 \%$ of the survey respondents indicated that the USSA had raised the profile of sustainability 'a lot'/'a reasonable amount'/'some'. Of these, $48 \%$ indicated that the effect had been substantial ('a lot'). 
Graph 2. Building the profile of sustainability

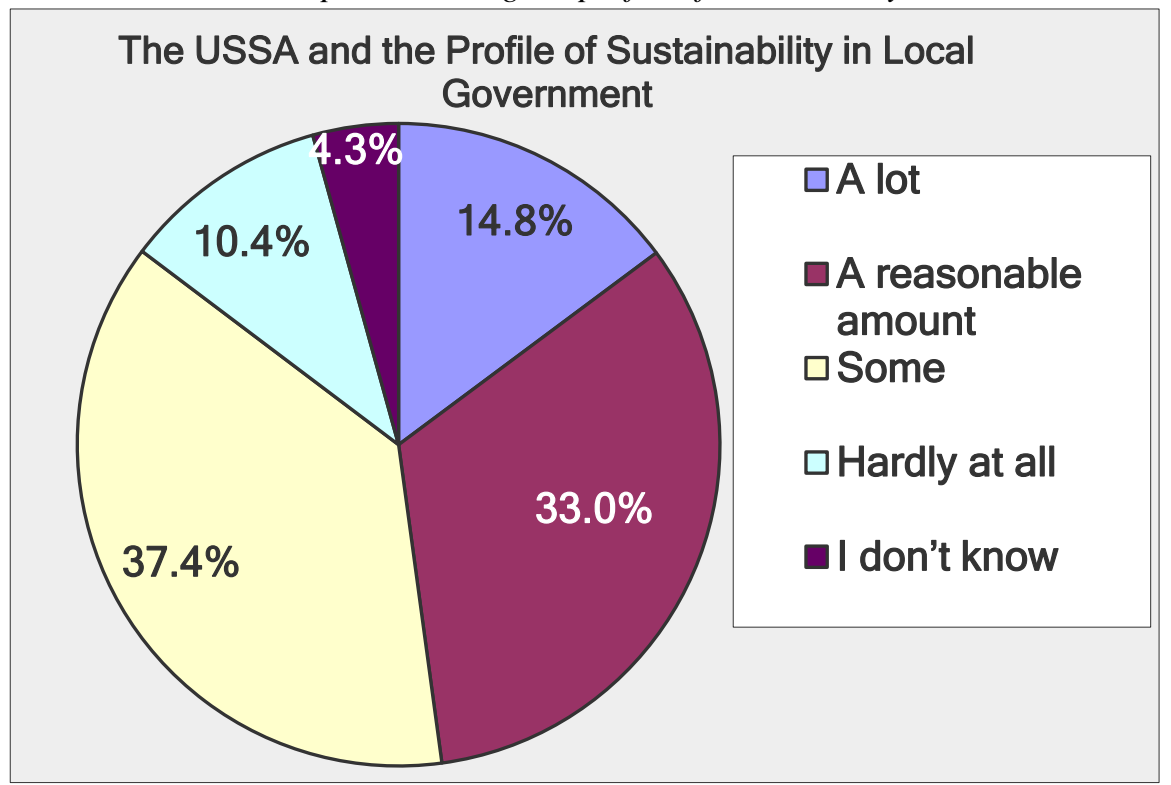

Almost $50 \%$ of respondents felt that their Council had made a solid beginning in the sustainability journey. A further $23 \%$ were of the view that their Council was 'quite advanced'/'very advanced'.

Table 1. The Sustainability Journey

$\begin{array}{lr}\text { I am not even aware there is a journey in my Council } & 1.0 \% \\ \text { My Council is interested but they have not done much } & 7.7 \% \\ \text { My Council has only just begun } & 18.6 \% \\ \text { My Council has made a solid beginning } & 49.5 \% \\ \text { My Council is quite well advanced } & 17.0 \% \\ \text { My Council is very well advanced } & 6.2 \%\end{array}$

According to the survey respondents the USSA was of value, as indicated in Graph 3 below:

Graph 3. Value of the USSA

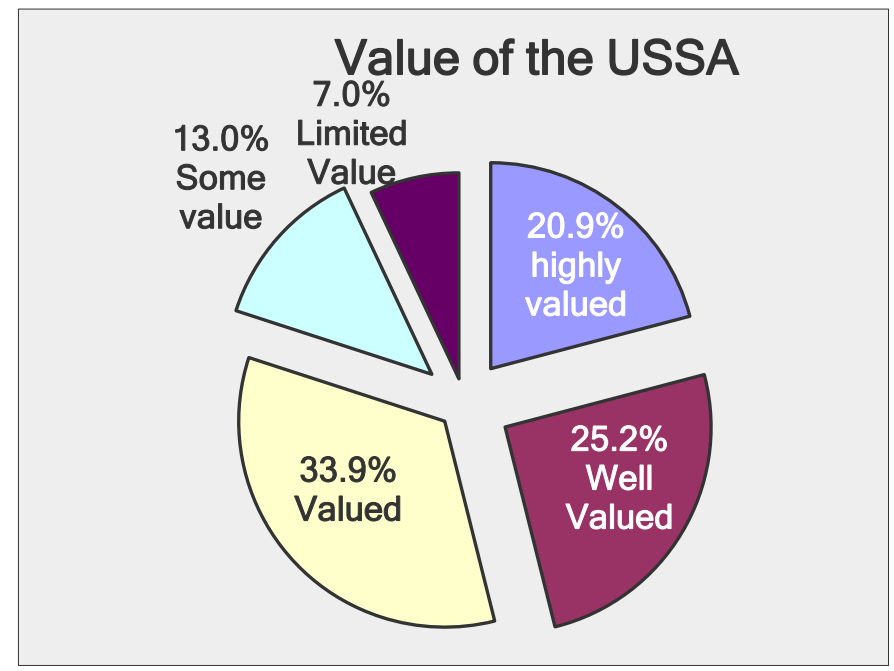

These are encouraging results and demonstrate that according to those in local government, sustainability is on the agenda-movement is happening. 
Finding re Outcome 2. There is evidence that the USSA cultivates networks and alliances of those working to innovate and make change. There is evidence that the USSA enhanced networking about sustainability. Graph 4 details the views of Council staff about the extent to which the USSA supported the networking process.

Graph 4. USSA and Networking

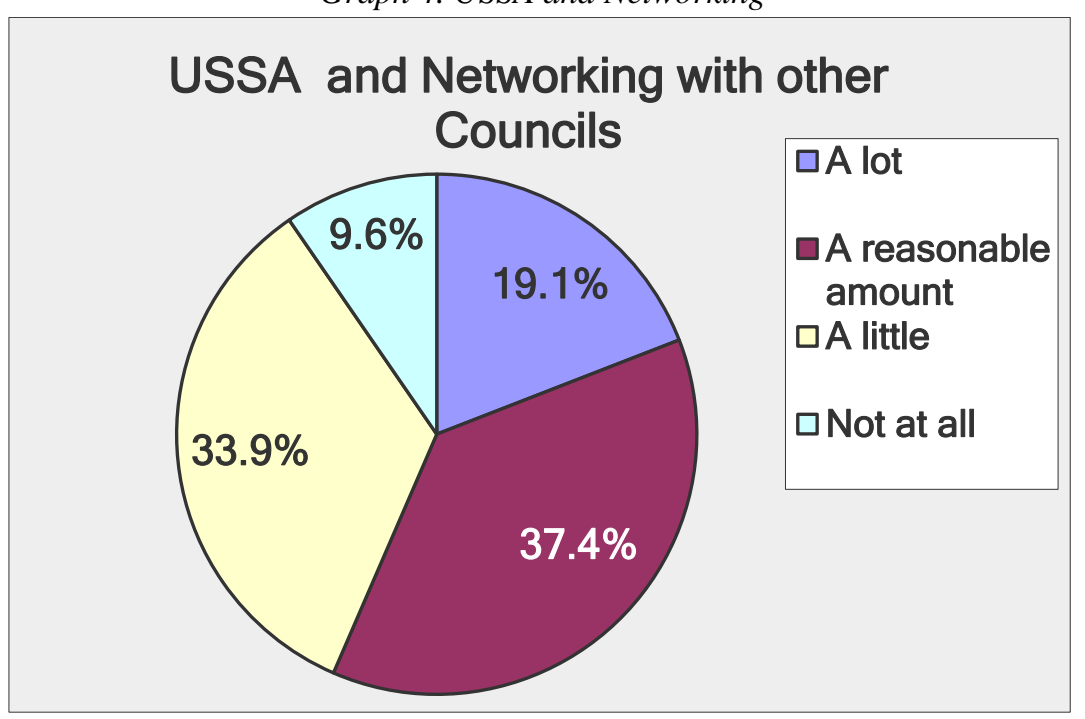

The integrated nature of the USSA added value. For example one respondent said that: In-house training helped add value to Council's staff sustainability programme (Green Champions) and the whole programme provided additional credibility and tools for spreading the sustainability message across Council. Sustainablenet continues to thrive as the network of choice for those interested in sustainability to share their understandings and ask questions of their peers.

The USSA delivered events and networks that enabled people to meet and communicate - to share ideas and approaches to integrating sustainability within Council business. For example: All the USSA events provide opportunity to meet and reconnect with staff at other Councils across Sydney, who we otherwise may not have ever met or exchanged ideas with. Local government needs cross-fertilisation between organisations to drive innovation and cultural change (focus group participant).

The following quote from a regional Council manager adds weight to these results:
I found the USSA highly valuable in my work on our Urban Sustainability Grant program. The cluster meetings, research material, ten tips etc. were especially useful at providing opportunity to share projects and key learning and generate ideas and discussion on existing and future projects. It was also helpful having the USSA there to discuss issues surrounding reporting and project planning which is a significant part of my program.

Finding re Outcome 3. Significant evidence exists that the USSA has identified existing resources and tools and helps link these to Council's urban sustainability work. Particular resources and tools provided by the USSA moved Councils forward. For example, the experience of one Sustainability officer was that:

The training was powerful for managers and helped them to set up financial and environmental sustainability together. Before that, people were not at all fussed about sustainability. Another said: Your programme has assisted the smaller Councils in our area. 
Since your programme has been running, these Councils do not seem to rely as much on the larger Councils to get information. I attribute this to the support being available through the USSA program.

Table 2 below indicates the extent of this engagement with various resources and tools across a four point scale - note the total sample size of local government staff for this data is 115 (a sub-set of the total survey sample). The breadth of the programme means that it is almost impossible that any single Council (respondent) will have engaged with all elements of the program.

In drilling down, it is of note that over $75 \%$ of all rural respondents had had no engagement with the research publications. Similarly a significant number had not engaged with the USSA website or guidance material and this provides room for more activity in the future.

Table 2. Extent of engagement with various elements of the USSA programme

\begin{tabular}{|c|c|c|c|c|}
\hline Answer Options & $\begin{array}{c}\text { Considerable } \\
\text { engagement }\end{array}$ & $\begin{array}{c}\text { Some } \\
\text { engagement }\end{array}$ & $\begin{array}{c}\text { A little } \\
\text { engagement }\end{array}$ & $\begin{array}{l}\text { Not a lot of } \\
\text { engagement }\end{array}$ \\
\hline $\begin{array}{l}\text { Sustainability Training } \\
\text { delivered by the USSA in my } \\
\text { Council or ROC }\end{array}$ & 19 & 44 & 20 & 32 \\
\hline $\begin{array}{l}\text { Network meetings coordinated } \\
\text { by the USSA e.g. Business } \\
\text { Network meetings }\end{array}$ & 8 & 30 & 24 & 53 \\
\hline Sustainability Health Check & 19 & 31 & 31 & 34 \\
\hline $\begin{array}{l}\text { Regional workshops offered } \\
\text { by the USSA for example: } \\
\text { Sustainability Planning } \\
\text { workshops }\end{array}$ & 15 & 37 & 23 & 40 \\
\hline $\begin{array}{l}\text { The Ten Tips series of } \\
\text { publications }\end{array}$ & 6 & 30 & 31 & 48 \\
\hline USSA Case studies & 14 & 40 & 33 & 28 \\
\hline $\begin{array}{l}\text { The Sustainability Tools } \\
\text { Selector workshops }\end{array}$ & 23 & 43 & 20 & 29 \\
\hline $\begin{array}{l}\text { Research materials for } \\
\text { example: Barriers and Drivers } \\
\text { Report }\end{array}$ & 15 & 30 & 28 & 42 \\
\hline The USSA website & 19 & 44 & 32 & 20 \\
\hline The USSA newsletters & 24 & 50 & 24 & 17 \\
\hline
\end{tabular}

Finding re Outcome 4. Evidence exists that the USSA identifies, facilitates, conducts and promotes relevant research which is of value to local government. The research aspects of the USSA were valued and reflected upon positively by those who engaged with this part of the program, although this element of the programme was probably less known than others.

There is evidence that some publications were highly valued and really made a difference - in particular the University of Technology Sydney Institute of Sustainable (2009) Barriers and Drivers to Sustainability in Local Government Report. One key informant respondent said: 
The Drivers and Barriers [sic] in the Sustainability document were so accurate to the situations faced by many Council officers and provided 'tried-and-tested' methods of getting past barriers.

Members of the focus group supported this view, rating this publication highly.

The Sustainability Tool Selector (Pillora S, and Blackburn N, 2009) seemed much more appropriate and useful to more advanced Councils, but was not used much in Councils at the earlier stage of their journey. Feedback ranged from: Sustainability Tool Selector - great to find out which tool to use when, what their uses and limitations are and how Councils have used them, to: this is beyond my Council's needs. It is notable though, that the Tool Selector workshops were well attended across NSW, and evaluated positively; for example, $90 \%$ of participants could identify how they had or would use the 'Selector' to progress their sustainability work.

Finding re Outcome 5. There is significant evidence that the USSA has promoted learning through professional development/training, advice and support: For almost all of the 2,076 local government personnel who attended USSA training during the life of the project, feedback was highly positive; one respondent, reflecting the views of many, said that: [training was]

\begin{abstract}
Fantastic and a very valuable mechanism for pushing staff towards sustainability. Another commented: The training has given our sustainability programme a significant boost. It would probably take some years to achieve that level of communication and support for sustainability without the training. Another said: I think it [sic, the training] is of very high quality and I feel that it is robust because it encourages Councils to use their own examples of what has and hasn't worked. It's based on real experience, not just training based on theoretical situations.
\end{abstract}

Participants were of the view that: Workshops provided sharing, brainstorming, networking opportunities that built on the web based resources important role in keeping sustainability on the agenda - building the profile and importance of human resources to drive these internally.

While more detailed data about the response to the training is available, it is difficult to provide detail in this paper because a number of different professional development programmes were offered through the USSA. Staff at all levels of the Council were engaged in purpose-built and relevant training.

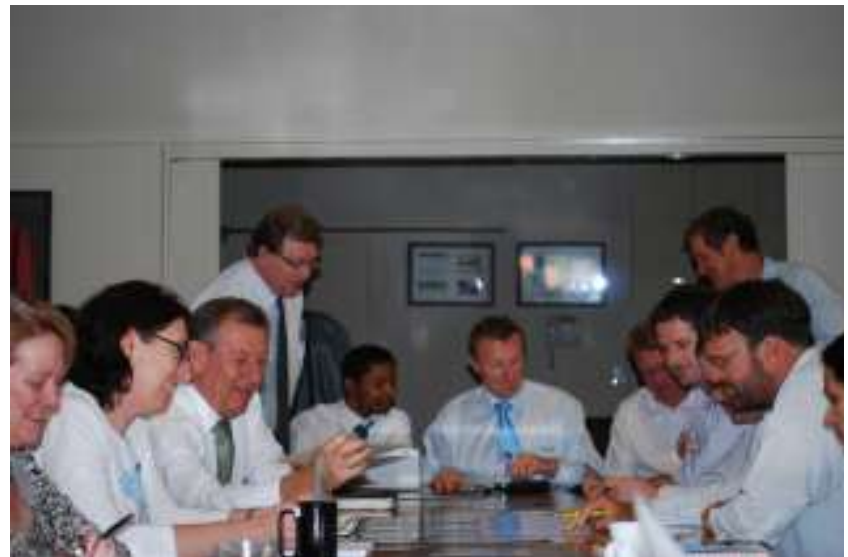

Canada Bay City Council Training

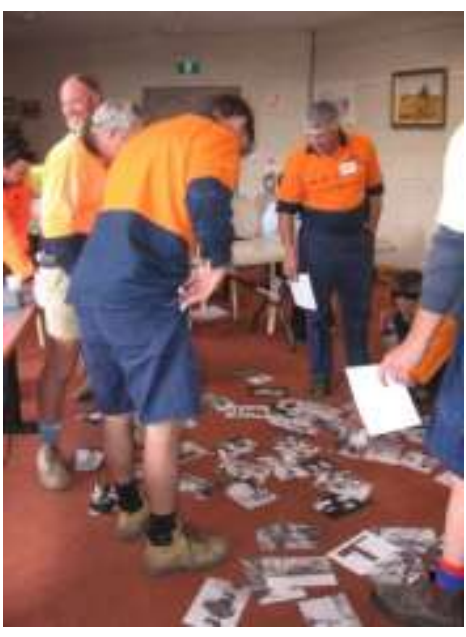

Operations Staff Training - Nambucca Council 
Some snapshot findings are:

- For the In-House Training, 41 Councils undertook programs, 78 workshops were delivered and 1,078 staff participated. All participants in all workshops demonstrated a shift towards a greater understanding of sustainability, identified actions that they would undertake as a result of the workshop and indicated that they were 'very' or 'highly satisfied' with the training.

- Councillor training involved the delivery of five workshops and 86 Councillors participated. All Councillors attending these workshops reported increased levels of understanding of ESD/sustainability and increased appreciation of Council best practice.

- Councillors indicated that they were committed to getting more involved in sustainable issues, championing sustainability in the community and assisting councils to improve sustainability performance.:

- The Evaluating Sustainability Programme involved 96 participants at six workshops. Ninety four percent of participants reported a positive shift in their knowledge of outcomes hierarchies and programme logic and that they would use information gained from the workshops in their future work

- Sustainability Health Check training involved seven Councils and 105 participants. As a result of the training:

- $\quad 89 \%$ of participants feel the SHC can assist Council to promote cultural change

- $95 \%$ of participants feel the SHC can encourage the analysis of Council's policies, systems and practices

- $71 \%$ of participants feel the SHC can improved governance

- $78 \%$ of participants feel the SHC can enhance Council's role in building and engaging community awareness

- $92 \%$ of participants feel the SHC can help promote a culture of sustainability across the organisation.

A challenge for the future is that staff and elected officials from over 100 Councils did not have the opportunity to attend in-depth training that was offered through the USSA program. There is much professional development still to be done.

Finding re Outcome 6. Some evidence exists that the USSA has built the profile of sustainability work within local government and amongst opinion leaders. People value the USSA. From the survey, 21\% of respondents valued it 'very highly' and a further 56\% were 'very positive'/'positive'. Almost 3,000 Council staff/elected officials have personally come into contact with the USSA through face-to-face training/workshops and network meetings during the life of the program. Many more have accessed the USSA materials, the website etc. and engaged though Sustainablenet and other on-line activity. 
Eighty six Councillors from across NSW also attended one-day training workshops, run through the LGSA’s Learning Solutions program.

As one focus group member said, the USSA: raised the bar on sustainability with our opinion leaders.

Finding re Outcome 7.There is a need for ongoing support for Local Government in NSW to continue to progress towards integrating sustainability. The evidence supporting this finding is very strong. There has been no suggestion that the job is done and Councils have completed 'the journey'. Even among those Councils where respondents to the survey indicated that their Council is "quite well advanced'(17\%) or 'well advanced'(6\%), there was no sense support was no longer required. Most Councils though, are not at this level. In the on-line survey, 50\% of respondents said that their Council had 'made a solid beginning' - a further $27 \%$ rated their Council at a lower level than this. No data at all is available from some $20 \%$ of Councils who did not respond to the request for input into this particular evaluation process. For Councils at the earlier stage of the journey there is significant evidence that continuing support is required. The following quote summaries the views of many:

I hope that it is possible to either continue the USSA in its current form or similar, as I think local Councils need the support of a body such as this. As I mentioned earlier, most Council staff I know are keen and able to consider sustainability as a higher priority than it is currently but need support and advice in how to shift attitudes and views of executive management.

Smaller Councils have particular needs for support and there are significant findings about options for providing this level of support more appropriately. Often the problem is not with the commitment to sustainability but with its practice:

In smaller Councils we are not lacking the ideas - we are not lacking the commitment or the willingness. We're lacking the people and the dollars.

Clearly the programme was effective but as indicated in the title of this paper, it provided 'a lot but not yet enough'.

\section{Conclusions}

The USSA was developed from scratch, in the absence of other models and examples of support structures for sustainability related organisational change in local government. When viewed within this context the results of the support processes delivered by the programme are exceptional. It is clear that the USSA really made a difference; it connected with local government staff and promoted cultural change, together with an improved understanding of sustainability and changes in policy, operations and procedures. This was much beyond the traditional Council roles of rates, roads and rubbish. 
The evaluation of the programme makes it clear that the uptake of sustainability is not consistent across all Councils. In this respect there is much remaining to be done; the public policy and legislation is in place, but cultural change of this level takes time, capacity and resources. There remain significant issues for Councils with a limited rate base, and resourcing issues for Councils obviously have an impact on uptake.

The recommendations from the evaluation report point to a number of key activities for the future, that are required to further progress the integration of sustainability. These include: specific interventions with smaller Councils with a limited rate-base; more training, and establishing a network for Councillors are important. Increased opportunities for Councils to learn from each other via mentoring or other approaches; more case studies and other examples of effective practice are also an important part of the mix. Most Councils still need the opportunity to engage with Quadruple Bottom Line $\{\mathrm{QBL}]$ thinking and planning, and the future should provide them with a supported opportunity to do this.

The journey continues.

\section{References}

Environmental Planning and Assessment Act 1979, viewed 14 February 2012:

http://www.legislation.nsw.gov.au/viewtop/inforce/act+203+1979+FIRST+0+N

Funnell, S (1997) Program logic: an adaptable tool for designing and evaluating programs, Evaluation News and Comment, vol. 6(1) Australasian Evaluation Society.

Funnell, S (2000) Developing and using a program theory matrix for program evaluation and performance monitoring, in Rogers, PJ et al, editors. Special Issue: Program Theory in Evaluation: Challenges and Opportunities. New Directions for Evaluation.200087:91-10. Jossey-Bass, San Francisco; 2000

Local Government Act 1993, viewed 14 February 2012: http://www.austlii.edu.au/au/legis/nsw/consol act/lga1993182

Local Government NSW Website viewed 22 July 2013: www.lgnsw.org.au

Local Government and Shires Associations (2011) Support the Journey of Local Government Towards Sustainability - An Evaluation of the Urban Sustainability Alliance. Http

Pillora S. and Blackburn N, (2009) Sustainability Tool Selector:

Pillora, S, Blackburn, N and Artist, S (2009) Barriers and drivers to sustainability in local government, prepared for the Urban Sustainability Support Alliance by the Institute for Sustainable Futures, University of Technology, Sydney.http://www.isf.uts.edu.au/publications/Pilloraetal2009BarriersandDrivers.pdf

Rogers, P (2008) Using program theory to evaluate complicated and complex aspects of interventions, Evaluation, 14(1).29-48. 